\title{
Eckhardt-Gramatté Music Library: Chronology of a Building Project
}

\section{by Janneka Guise}

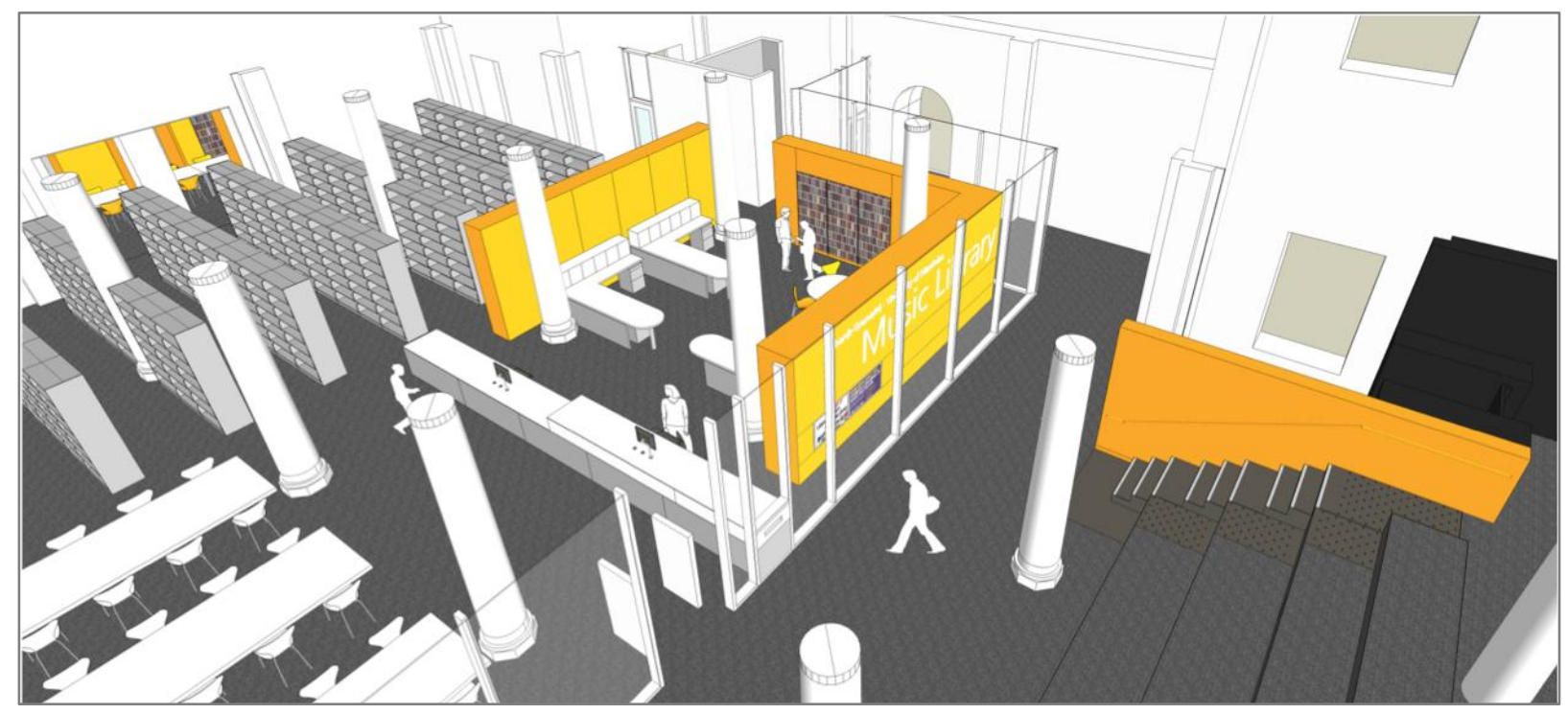

Figure 1. Library entrance @ Patkau Architects

\section{Abstract}

On August 10, 2015, the Eckhardt-Gramatté Music Library closed the doors of the space it had occupied at 65 Dafoe Rd at the University of Manitoba since it opened in 1965, and prepared to move to its new home down the street in the Taché Arts Complex, 136 Dafoe Rd. The move itself took three days, and was the culmination of eight years of planning, design, and preparation. The Library re-opened in its new home approximately one month later, on September 26, 2015. The new space is 2.5 times larger than the old, has nearly three times the number of student study seats, and every shelf has room for growth. This article documents a brief history of the Library, and chronicles the move to the new location from the announcement in 2008, through the space planning, design, and construction phases, to moving day and beyond. At the end of the article is an overview of lessons learned and a recommended reading list for anyone lucky enough to enter into a new library building project.

Janneka Guise (Jan.Guise@umanitoba.ca), MMus, MLIS, is Head of the Eckhardt-Gramatté Music Library, University of Manitoba.

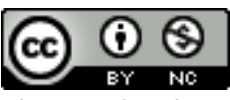

This work is licensed under a Creative Commons Attribution-NonCommercial 4.0 International License. 


\section{Background}

In 1965 the School of Music at the University of Manitoba ( $U$ of M) opened a reading room in one of its classrooms. Staffing consisted of two full-time library assistants (support staff). In 1982 the reading room doubled its space by expanding into an adjoining classroom to become the Music Library, with three full-time support staff and a librarian as head. The Library now held books, periodicals, music scores, and sound recordings to support research, study, and teaching in the School of Music. In 1992 the Eckhardt-Gramatté Foundation in Winnipeg made a $\$ 500,000$ gift to the $\mathrm{U}$ of $\mathrm{M}$. The money was put into a trust fund, with the annual interest to be used for enhancing the Music Library collection. That same year, the library was named the Eckhardt-Gramatté Music Library. The annual interest on the trust fund is divided each year between the Eckhardt-Gramatté Music Library and the ensemble libraries of what is now the Desautels Faculty of Music (DFoM).

Today the DFoM has an enrollment of approximately 275 students. Most are undergraduates in the Bachelor of Music or Bachelor of Jazz Studies programmes. The DFoM also has a small graduate programme offering Masters degrees in performance, conducting, and composition.

The Eckhardt-Gramatté Music Library supports these programmes with a collection of approximately 11,000 books, 30,000 music scores, and 9,000 sound recordings. There are two full-time support staff, zero part-time support staff, and one MLIS music specialist librarian who serves as head (the author).

By the early 2000s, both the music faculty and the Eckhardt-Gramatté Music Library had outgrown the building they shared. The Library had only 12 listening carrels and 12 additional seats for student study. Of those seats, nine were taken up with desktop computers for public use, so tabletop space was limited for notebooks, music scores, and any other research or reference items. The book and score stacks were crowded to the point where many sections had zero room for growth. The staff work area shared by the support staff and the librarian was small and crowded, with no spare workspace, no privacy, and no sink for binding or preservation activities.

Despite these deficiencies, the Library maintained an excellent relationship with the DFoM staff, faculty, and students. The Library was a bustling space with high usage statistics. The Head is a full member of the DFoM Council, and regularly collaborates with faculty members on information literacy and collections projects.

Planning for a new Centre for Music, Art, and Design (CMAD) at the $U$ of $M$ began in 2002, led by the architectural team of LM Architectural Group (Winnipeg, MB) and Patkau Architects (Vancouver, BC). This project was meant to address space challenges in the School of Art, the DFoM (then the School of Music), the Fine Art/Architecture Library, and the Music Library. For several reasons, the CMAD project was abandoned by the University shortly after the award-winning design was completed (Award of Excellence 2005). 
In 2008 the $\mathrm{U}$ of $\mathrm{M}$ launched Project Domino, an ambitious cross-campus renovation project in which one building would be renovated, a department would move in, then that department's former home would be renovated so a different department could move in, and so on. The project began with construction of a new student residence, Pembina Hall, which opened in Fall 2011. Next, the historic Taché Hall residence was vacated and renovations began on what would become the Taché Arts Complex: the future home of the DFoM, the School of Art, and the Eckhardt-Gramatte Music Library. Five years later, we moved into our new spaces. ${ }^{1}$

Once CMAD was announced, followed by Project Domino, the $U$ of M Libraries' Administration was understandably reluctant to put new money into the old Music Library facilities, despite their deteriorating condition. The staff and student desks were mismatched hand-me-downs from the campus Re-Shop (where gently used furniture from other departments gets re-purposed). The student chairs were equally mismatched, and often damaged or broken due to years of use.

Fortunately, there was never any doubt that the Eckhardt-Gramatte Music Library would move with the DFoM. Firstly, the old library space was earmarked for another department as part of Project Domino, so the Library would have to move somewhere. No other $U$ of $M$ library had space to subsume the music collection. Secondly, in my role as Head, I wrote a space planning/library profile document that articulated the vision and values of the Eckhardt-Gramatte Music Library. This document (described below) helped senior administrators at the University understand the role of the Library in the DFoM and the importance in keeping the collection together in one place. Thirdly, the Dean of DFoM supported the library profile document, recognized the importance of keeping the Library embedded in the Faculty, and was willing to allocate space in Taché Hall to the Library.

Due to recent closures and amalgamations of music libraries across the country, as of this writing, the Eckhardt-Gramatté Music Library is the last remaining embedded music library in Western Canada.

\section{Early Years (2008-2010)}

The Taché Hall/Taché Arts Complex project was awarded to LM Architecture Group (Winnipeg, MB)/Patkau Architects (Vancouver, BC) in late 2008. This was the same team that had worked on CMAD, so they were already familiar with the local environment. Because the defunct CMAD project was so recent, I had a wealth of local experience and documentation from which to draw. I prepared a Space Plan/Library Profile document in December 2008, based on work done for CMAD by the Head, Architecture/Fine Arts and Music. The purpose of a Space Plan/Library Profile is:

- To orient the architects to the library space, users, collections, and staff;

- To help clarify a vision and values for the Library, which are essential to keep design of the new space on track;

1. Unlike the CMAD project, and despite the School of Art moving to the Taché Arts Complex, Project Domino was never designed to move, replace, or enhance the Fine Art/Architecture Library. It remains in its original space in the Russell Building (Faculty of Architecture). 
- To calculate collection growth rate, and decide on additional space needed for collections in the new Library; and

- To plan spaces for users and staff, and forecast technology needs.

When planning a new library space, it is difficult to forecast future needs: calculating the growth rate of the collection in a time when academic libraries are shifting to more online resources; planning for student spaces and library technology in a time when mobile devices are on the rise and wireless internet is nearly ubiquitous; planning workspace for library staff in a time when budgets are shrinking and staff complements are volatile. The best we can do is consult the literature, talk to colleagues from other libraries, learn from the architects who have experience designing spaces within these shifting paradigms, and then make an educated guess.

We began meeting with the architects in early 2009. In the early stages, the Head, Architecture/Fine Arts \& Music Libraries and I attended meetings together. In later years I attended the meetings on my own, and consulted as needed with the Head, Architecture/Fine Arts \& Music Libraries. The architects used the Library Profile to design an initial set of functional areas for the Library, then used these functional areas as the basis for face-to-face discussion. The functional areas were like individual jigsaw pieces: one for book stacks, one for staff workstations, one for a student photocopier room, one for a staff lounge, one for a student listening area, and so on. In face-to-face discussions with the architects, I had a chance to provide additional details to ensure each jigsaw piece was the right shape: $\mathrm{x}$ linear $\mathrm{ft}$. of book stacks; y staff workstations (each with a bookshelf, certain size of desk, computer, two monitors, file drawers, etc.); a student copier room (one copier, one printer with its own computer workstation, one card reader, a table with paper cutter, hole punch, stapler, etc.). The architects also asked about proximity of the functional areas to each other. For example, does the student photocopier room need to be near the service desk? Do the staff workstations need to be near the service desk? Will the librarian have a private office, and where should it be in relation to everything else?

Early in 2010 the architects were looking for an appropriate place to put the Library within Taché Hall. The former cafeteria was deemed ideal: a large open space, with oak paneling, many windows, and a central location as the "heart" of the building (see fig. 2 and fig. 3). However, the architects were concerned about floor loading. My research for the Library Profile document had shown that library stacks are very heavy, and that music stacks are heavier still: steel shelving carrying the weight of thousands of densely shelved music scores, vinyl LPs, and plastic/metal CDs. Music libraries therefore require a standard load bearing of $300 \mathrm{lbs}$./sq. $\mathrm{ft}$., which is much higher than the $150 \mathrm{lbs} . / \mathrm{sq}$. $\mathrm{ft}$. required for offices or classrooms (Cassaro 1991). Reinforcing the floor of a historic building like Taché Hall to accommodate a load bearing of $300 \mathrm{lbs}$./sq. $\mathrm{ft}$. was a cost deemed prohibitive by the $\mathrm{U}$ of $\mathrm{M}$. The University administration asked the University Librarian, who then asked me, to come up with an alternative for housing the collection. The University Librarian suggested we split the collection, placing the books and periodicals into the Elizabeth Dafoe Library (the $U$ of M's social sciences and humanities collections) and maintaining only music scores and sound recordings in the Eckhardt-Gramatté Music Library. 

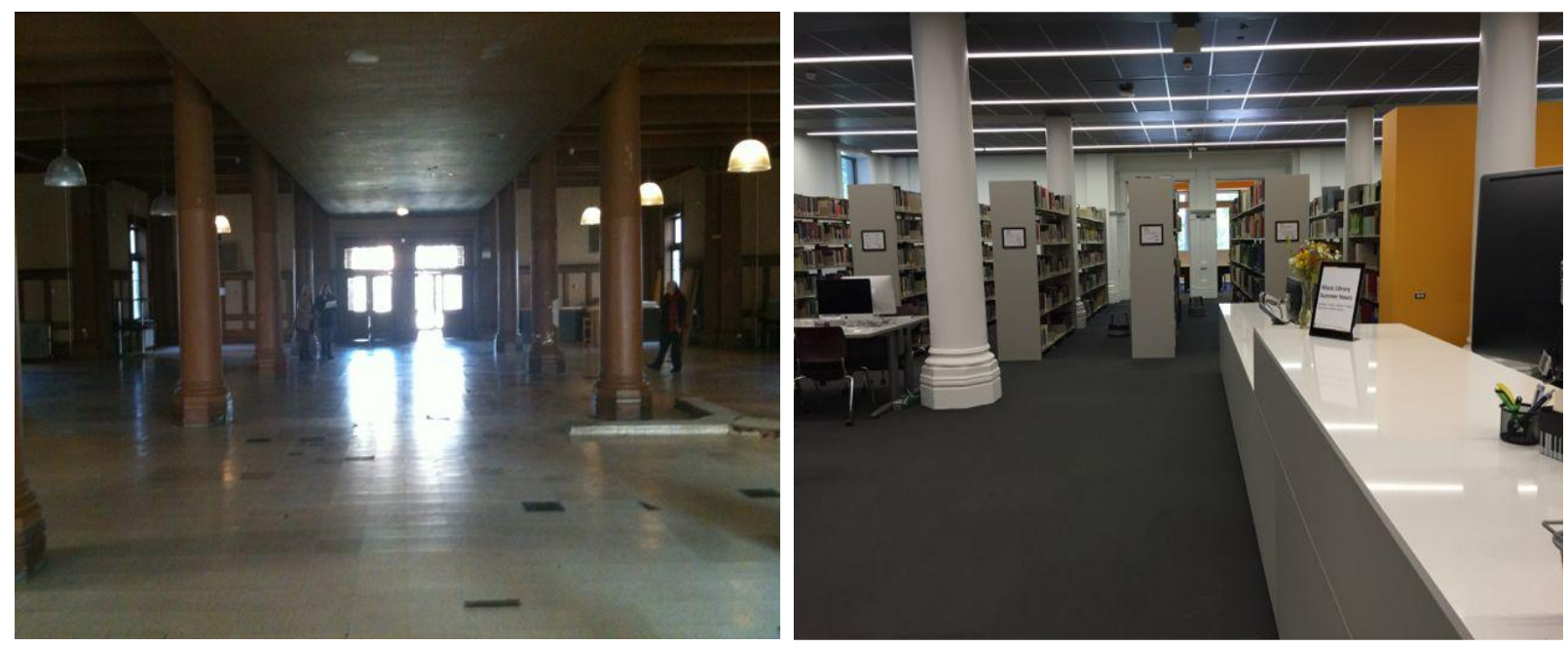

Figure 2. Facing north then (L) and now (R)
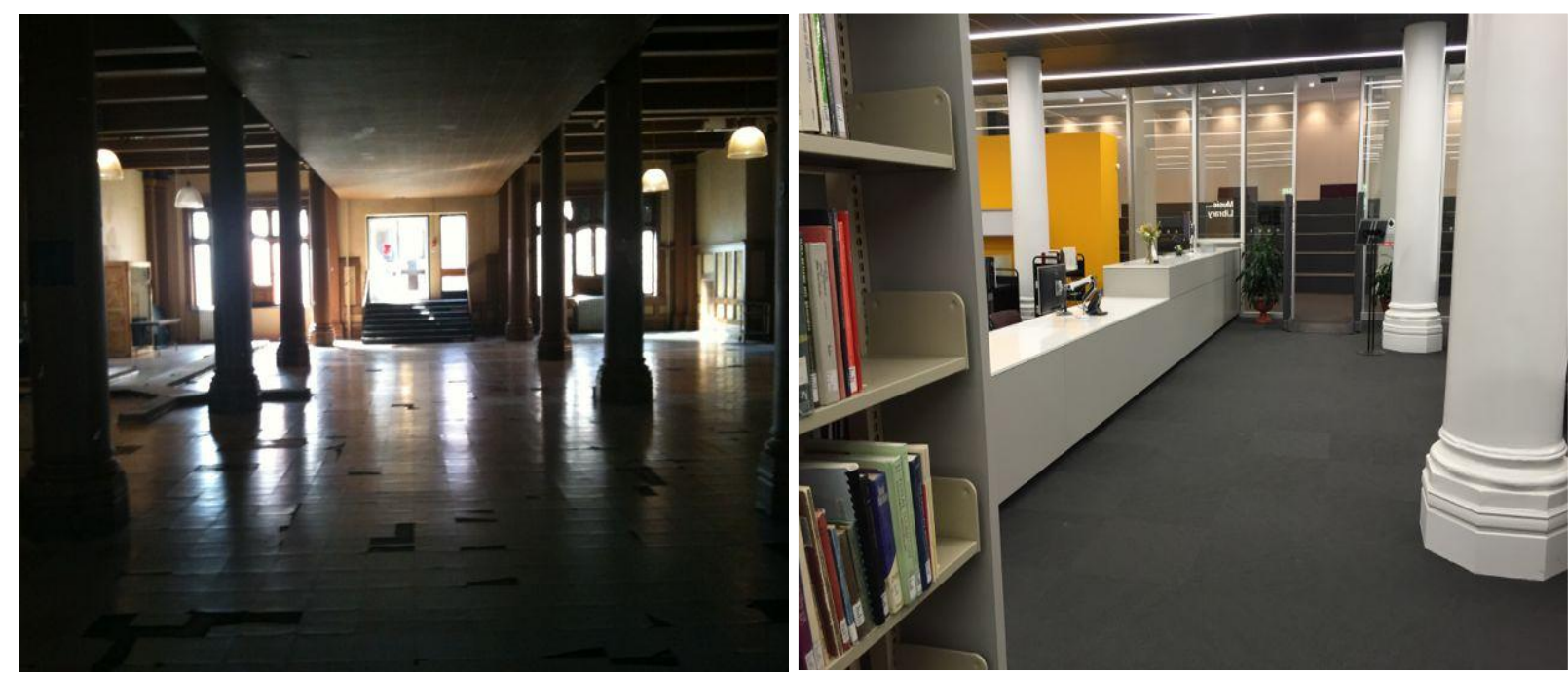

Figure 3. Facing south then (L) and now (R)

I returned to the Space Plan/Library Profile from 2008 and revised it. I reviewed my vision and values for the Music Library with the library staff and with the Dean of Music. Splitting the collection would not solve the floor load issue, since the music scores and sound recordings are heavier than the books and periodicals. The Dafoe Library did not have space to accommodate the music books and periodicals in any case. The Dean of Music and I were committed to an "integrated, relevant, collaborative space which supports the Desautels Faculty of Music's mission 'to provide a broad range of opportunity for music study and to produce creative and scholarly work...' and their vision of being 'a national and international centre of excellence in academic programs and music performance'" (Guise 2010). Therefore, logistically and philosophically, it made most sense to keep the Music Library's collection together and embedded within the DFoM. The architects determined the best way to accomplish this without reinforcing the floor was to spread the load across a larger area by designing book stacks with 48 " aisles (aisles are normally 36" for accessibility purposes). This compromise allowed the architects to 
place the Library in its central location as envisioned. Figure 4 shows the floor plan of Level 200 of the Taché Arts Complex. The Music Library is the large space in the middle of the drawing, with DFoM in the West Wing and the School of Art in the East Wing.

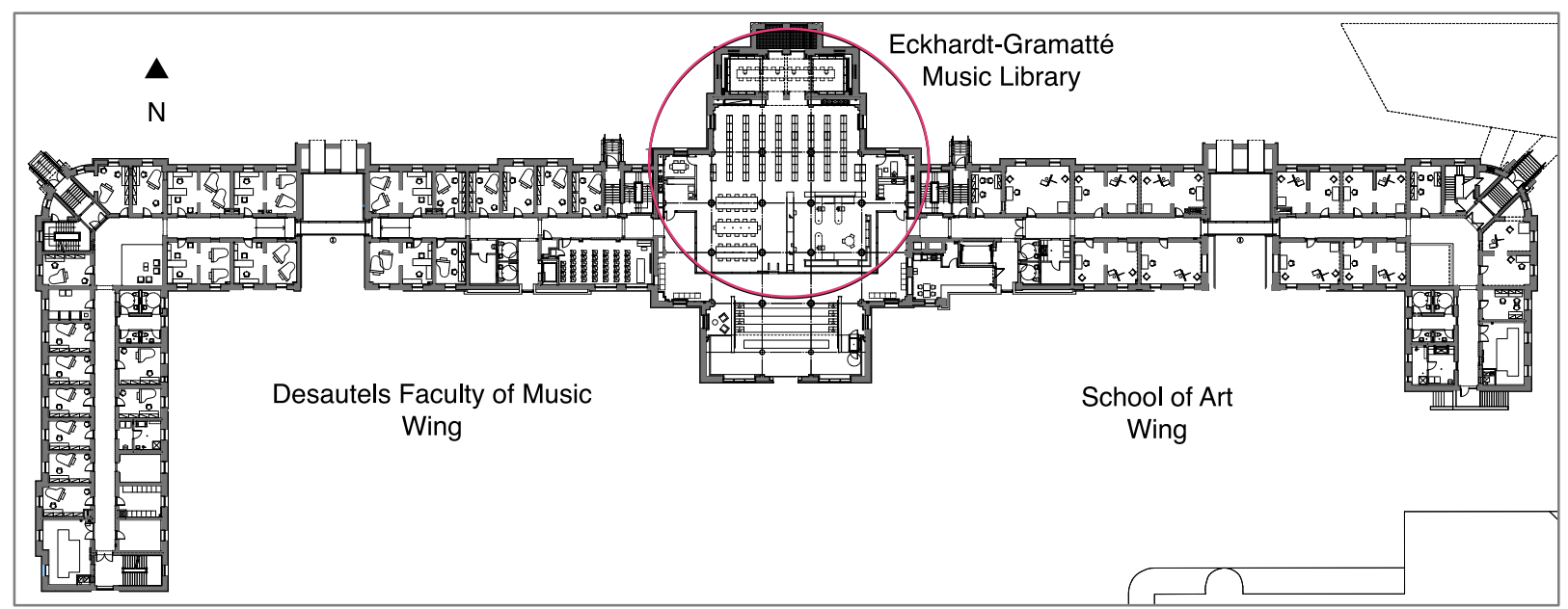

Figure 4. Level 200, Taché Arts Complex @ LM Architectural Group

\section{Middle Years (2011-2014)}

Once the architects had developed the functional areas and solved the floor load issue, they produced a draft floor plan for the whole Library in late 2010. At that point, I worked with the staff to discuss such considerations as the layout of the book stacks in relation to the public seating and front entrance, the location of the service counter and staff workstations, and traffic flow in the corridor outside the Library. We asked each other questions like, "What do we want patrons to see when they walk into the Library: book stacks or study tables?" The walls separating the Library from the corridor are glass (see fig. 1), so we also asked, "What do we want patrons to see as they walk past the Library: their friends studying or rows of book stacks?" I took all comments, questions, and feedback to the architects at scheduled meetings or via e-mail. The architects used this feedback when generating subsequent drafts. This process took approximately two years; the floor plan layout was not finalized until late 2012 (see fig. 5). 


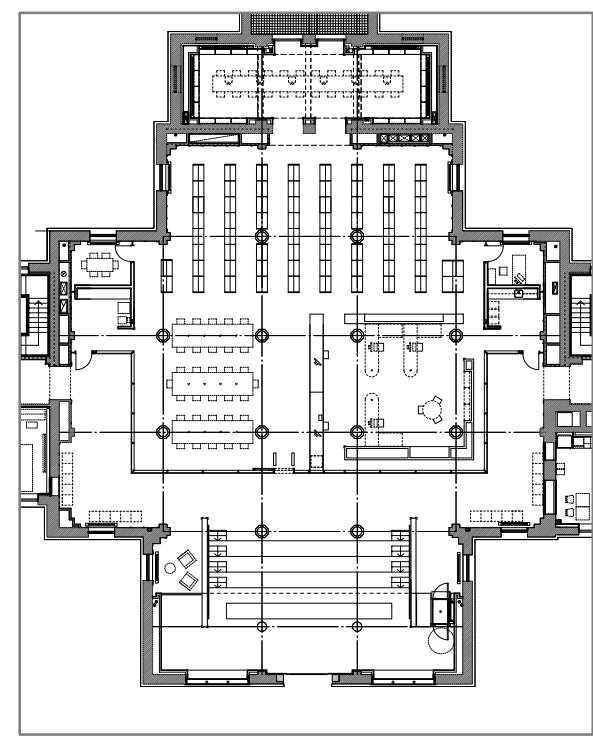

Figure 5. Floor plan, Eckhardt-Gramatté Music Library @ LM Architectural Group

One of the most challenging areas to design was the layout of the staff workstations. We value great customer service and wanted to orient our workstations so any staff member could see the service desk. That way we could avoid scheduling "desk shifts." Figure 6 shows the final orientation of staff workstations (two support staff in the front seats, librarian in the rear seat). The architects also designed a private office behind the staff workstations. The office is shared by the librarian and the support staff, and used whenever privacy or a quiet work space is needed.

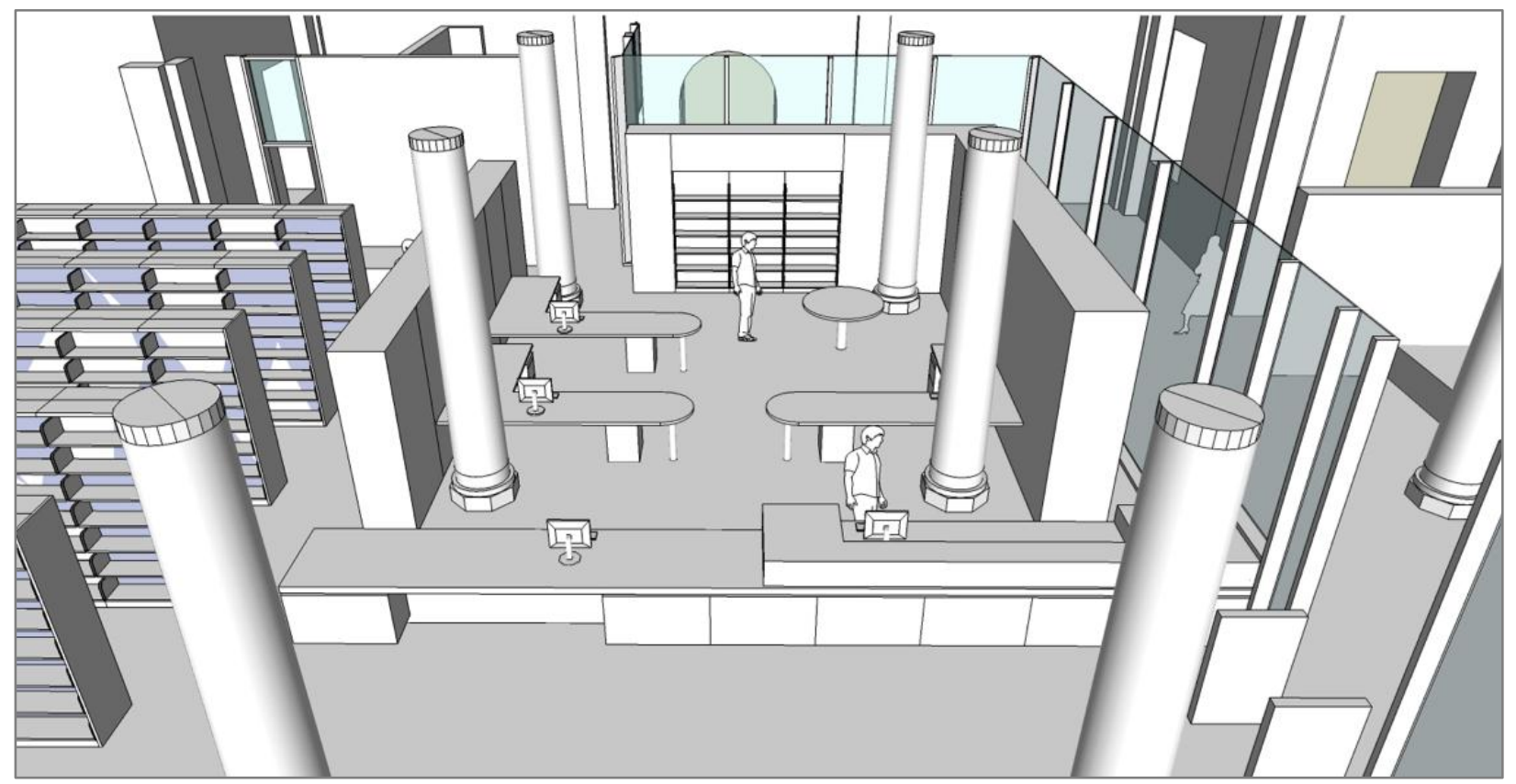

Figure 6. Orientation of staff workstations (c) Patkau Architects 


\section{Mechanical, Colours, Finishes, Furniture}

Once the overall floor plan was approved, the architects began filling in the details. In 2013, I reviewed the mechanical drawings with our local Project Coordinator in Physical Plant. These drawings indicate positioning of sprinklers, power outlets, lighting, data ports, and heating/ventilation/air conditioning. I was particularly interested in reviewing the lighting, to ensure the book stacks would be well lit, and the number and position of all the power and data outlets (for staff workstations and for student computing). It was valuable to have the Project Coordinator (who is also an architect) to interpret the drawings for me.

It took more than two years of consultation to settle on colours and finishes for the Library. Figure 1 shows the colour scheme, which is basically a black/white/grey palette with a pop of colour (yellow). Because the pop of colour also appears in the DFoM, both the Faculty and the Library had to approve it. Initially, the architects suggested bright green, which was rejected by the DFoM. They came back with indigo, which was also rejected. The third draft had no colour at all, just black. The Library staff rejected this as too dark, because all three walls and the ceiling around the staff workstations would be black. The fourth proposal, a warm yellow, was approved by all involved.

The architects also suggested finishes of carpet tiles for the flooring and laminate for the millwork. The architects had to control costs, which limited our choices. We told the architects that music students come into the library toting backpacks and hard instrument cases which would leave marks on the facing of the service counter. The library staff was concerned that the basic black/white/grey palette would be too cold and uninviting for users, and sought ways to warm up the space with different finishes. Cost prohibited a wood finish on the service counter, and the architects rejected our proposal of a "woodlook" laminate. In the end, we accepted the architects' palette, and worked to warm up the space with furniture choices.

In early 2015 we began working with the $U$ of M's Interior Designer to select furniture for the new Library: desks and chairs for staff, and tables and chairs for public seating. The public desks are made by Teknion (http://www.teknion.com/ca) and have a durable light grey laminate surface. They are wired into the floor so users can charge mobile devices in accessible power outlets on the tabletops. The Interior Designer suggested three candidates for the public seats, and had sample chairs sent by the manufacturer for our users to test. We tracked user preferences during the test period and decided on Grazie chairs made by KI (http://www.ki.com/products/name/grazie-stack-chair/). We added casters so they would be easy to move and not tear the carpet. All three staff desks are made by Humanscale. They have a manual lift mechanism allowing staff to work sitting or standing, and a medium-brown wooden surface (http://www.humanscale.com/). The interior designer met with Music Library staff multiple times to discuss furniture colours, and staff had several weeks to discuss choices for the desk tops and chairs. Figure 7 shows the light grey tabletops with burgundy chairs for public use. 


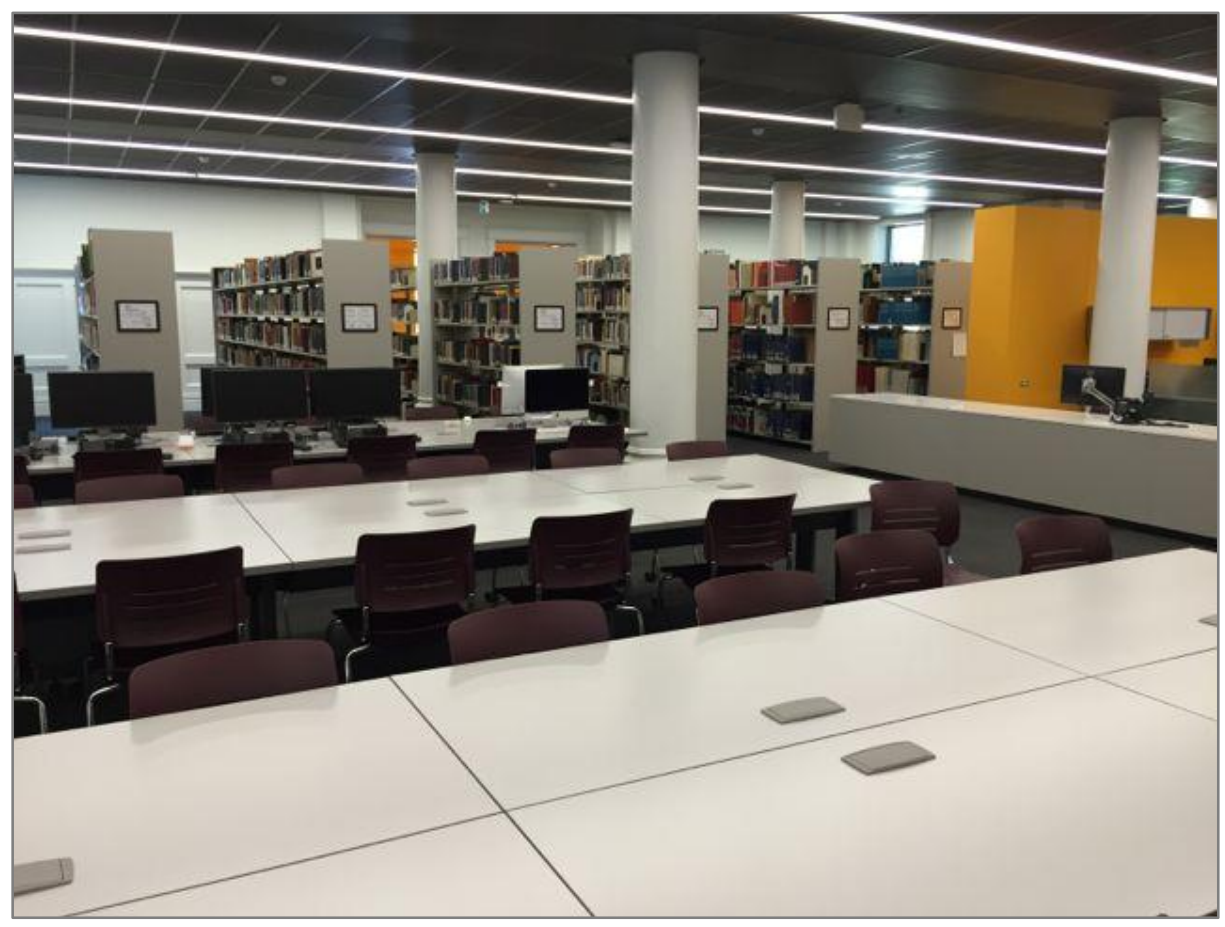

Figure 7. Public seating

\section{Shelving inventory/re-using old shelving}

In approving the budget for the renovation of Taché Hall for DFoM and the Music Library, the University Administration rejected the cost of purchasing new library shelving. This meant re-using existing shelving in the new space. Fortunately, we received funding through the construction budget to purchase new end panels for the shelving ranges, to give a finished, polished look to the book stacks (visible in fig. 7). Also fortunately, this decision was made in 2010 and I had several years to find gentlyused shelving for the new library. I knew that other $\mathrm{U}$ of $\mathrm{M}$ Libraries were planning to downsize their collections. The existing shelving in the old Music Library, with its different vintages, styles and colours (white, beige, yellow, orange, olive green) was unsuitable for re-use, so I took care to check any surplus from other $\mathrm{U}$ of $\mathrm{M}$ libraries as it became available and earmark shelving of one colour and style for the new library.

Although it is environmentally friendly to re-use library shelving, there were many challenges to overcome: finding long-term storage on campus; keeping an accurate inventory (pallets of shrinkwrapped shelves are hard to count!); ensuring the inventory included all upright posts, screws, feet, and cross-braces needed for re-assembly; locating and marking shelves of various depths for various music library formats (8"-deep shelves for CDs, 12" shelves for LPs and music scores, 10" shelves for books, etc.); clearly labeling the shelving as "For Music Library" so other libraries would not remove it; devising an inventory spreadsheet to track how many shelves and posts to save for each section of the new library and the location of these items in storage. 


\section{Pre-Move (2015-2016)}

Fortunately, one of our library assistants found Steven Fortreide's (2010) book entitled Moving Your Library: Getting the Collection from Here to There. This book contains spreadsheets designed to help take an existing collection and plan the shelving layout in a new space. The templates are available online, which means library staff can begin data entry immediately without having to re-create the spreadsheets. First you measure the linear feet of material and of free space on each shelf, and enter all those numbers into the spreadsheet. Then you enter the number of bays and shelves you have available in the new library, and the spreadsheet works out an appropriate layout: e.g., if a shelf is 36 " long (standard length), it fills each shelf to $26^{\prime \prime}$ and leaves $10^{\prime \prime}$ of free space. Fortreide's book is very easy to follow, and allows you to make corrections on the fly. For example, if you suddenly find you have fewer available shelves than you thought, you can change that number and the spreadsheet will adjust the fillrate for each shelf.

Preparing to move the stored shelving to the new library presented many challenges. Clearly, the shelving had to be delivered to the construction site and installed prior to moving day. The scheduling of moving day was dependent on the City of Winnipeg granting an occupancy permit. The inspection for the permit was rescheduled several times to accommodate work delays at the construction site. In addition, moving companies are very busy in August, especially at the beginning and end of the month, and we needed to ensure their availability. We therefore scheduled moving to begin Wednesday, August $12,2015$.

The occupancy permit was granted at the end of the day on Friday, August 7. That left Monday, August 10 to move all the stored shelving to the new library site, and Tuesday, August 11 for assembly. Because the building was still a construction site, a loading dock was not yet built. I worked directly with the construction company and the movers to find a suitable parking spot for the truck to unload the library shelving as close to the door as possible and to ensure the movers could have priority use of the elevator. The shelving was in shrink-wrapped stacks on pallets, and the movers were able to load them into their truck and bring them onto the elevator up to the library entrance. Unfortunately, the pallets would not fit through the library entrance door. The movers had to carry individual shelves by hand and stack them on the floor.

Equally unfortunately, new carpet had just been installed in the Library and in the corridor outside. To protect the carpet from the stacks of shelving, I worked with the construction company, who provided plastic sheeting and plywood.

The shelving installer was available on the right day, but I was concerned that the assembly might not go smoothly. The shelving had been in storage for so long, what if it was bent or broken? Would there be enough extra shelves for such emergencies? What if individual pieces were not compatible? What if my inventory was inaccurate and there weren't enough shelves for the collection? 
Despite the tight timelines, small margin of error, and my concerns about assembly, the shelving was moved and installed on time, and proved completely functional. After the assembly and installation, staff quickly cleaned each shelf (they were filthy from being in storage so long) and used painters' tape to mark the fill-level of each shelf according to the Fortreide (2010) system (see above). On moving day, we simply told the movers to fill each shelf to the tape mark, then removed the tape with no problems. Figure 8 shows the shelving with the new end panels, range finders, and library materials; it is difficult to tell that it is not brand-new.

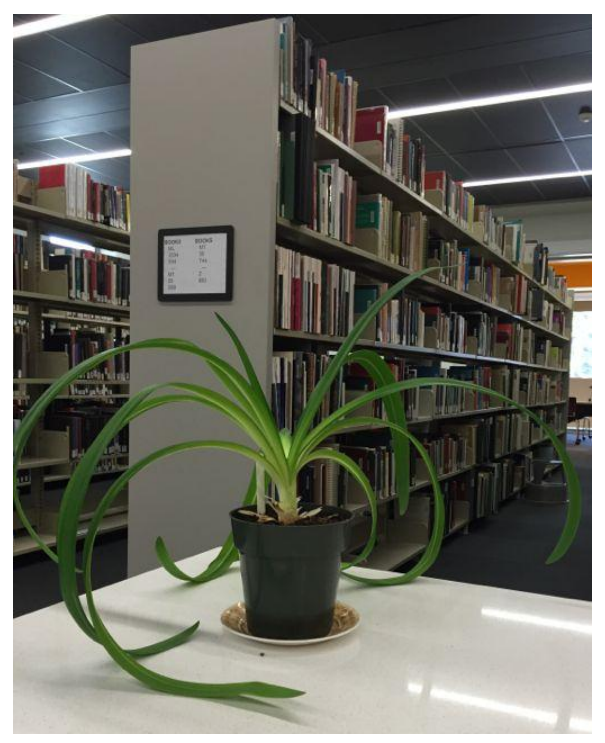

Figure 8. Completed shelving

\section{Choosing Movers}

To satisfy the $\mathrm{U}$ of $\mathrm{M}$ financial policy, we were required to get quotes from three moving companies. We approached three local companies that the University had used for various jobs. Each sent a representative to the Library to evaluate the size of the collection, the different needs for different formats, as well as the furniture that would be moved. Much of the furniture in the old library would not be moved, since new items had been ordered. Two of the three quotes recommended packing the library collection into boxes, but the third recommended the use of wheeled carts (like large wooden book trucks on wheels) for the books, journals, scores, and LPs (see fig. 9). Using carts meant the movers could keep the collection in order as it was packed and unpacked onto the new shelves. We knew this would save valuable time in shelf reading once the collection was moved, and the University accepted this justification for hiring the third company. The carts would be loaded, wheeled onto the moving truck, driven down the road to the new library and wheeled inside. To move the CDs, this company would rent Frogboxes ${ }^{\mathrm{TM}}$ (www.frogbox.com). These are large plastic bins with fold-over tops which, when closed, allow the bins to be stacked. They would be delivered to the old library ahead of time, as would the wooden carts for the rest of the collection, so on moving day the movers could start packing right away. 
I was the primary contact person for the moving company, and had several face-to-face and telephone meetings with their manager to determine how many days the move would take, the start date, the number of movers needed, and the role of library staff on moving day.

Once we knew the movers' workflow, library staff brainstormed a plan for moving day. We knew there would be movers at the old library, packing Frogboxes ${ }^{\mathrm{TM}}$ and wooden carts, a driver to take full boxes and carts to the new library site, and movers at the new library, simultaneously unpacking boxes and carts while new ones were being packed. We had enough staff to deploy two people at each location to oversee operations. Library staff were responsible for teaching the movers how to pack the collection to keep it in order (the movers did not intuitively understand to pack one shelf then move DOWN to the next shelf in the bay, rather than across to the adjacent shelf in the next bay, for example) and how to unpack it at the other end. Staff also devised a labeling system, whereby a loaded cart was labeled with the first and last call numbers (see fig. 10). That way, once seven or eight carts were lined up in the hallway, we knew the order for unpacking.

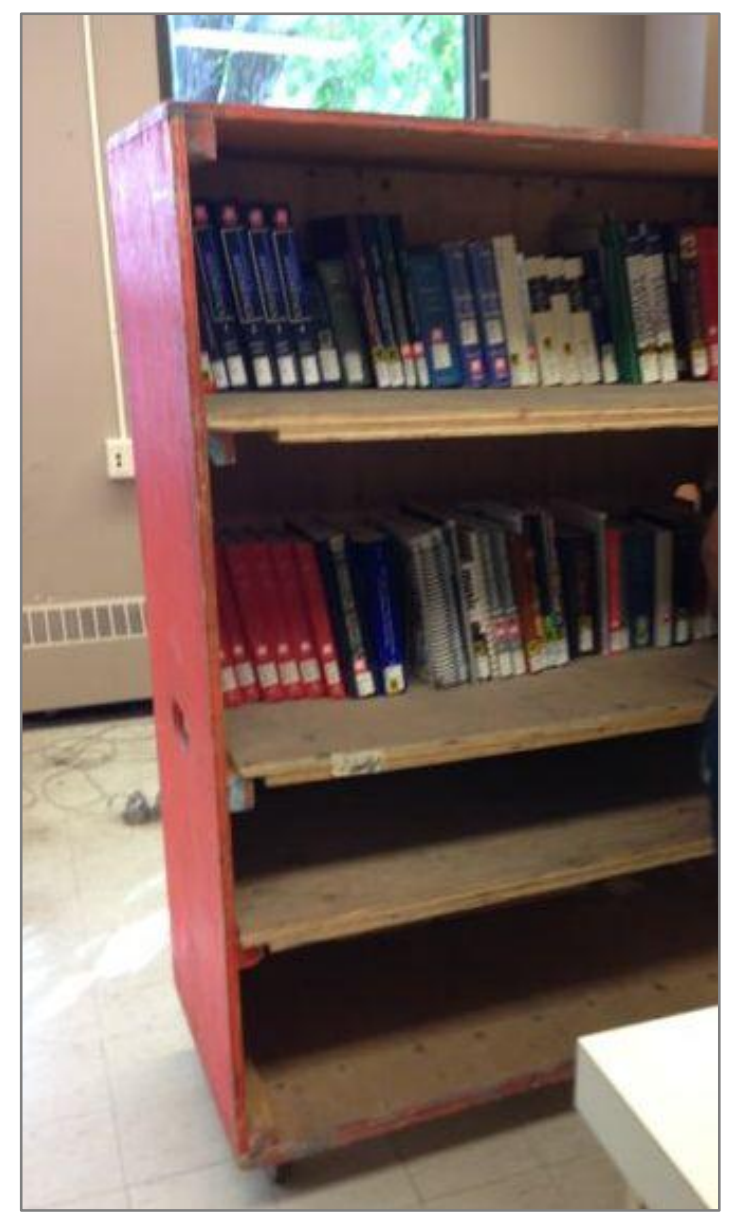

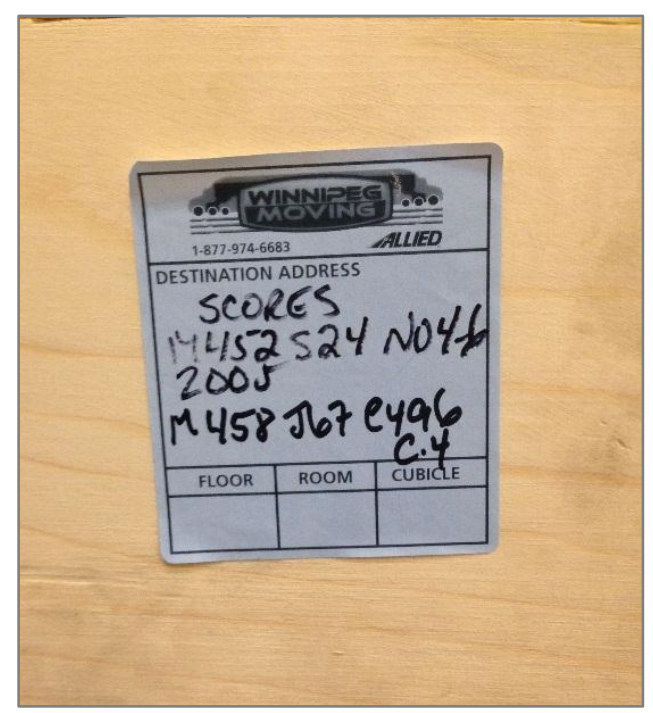

Figure 10. First and last call number (label on cart)

Figure 9. Wooden moving cart 
Communication was crucial in the months, weeks, and days leading up to the move. We expected to move in July or August, which meant notifying faculty and students in April before everyone dispersed for the summer. There was much communication between music library staff and other campus units as we planned for: cancelling inter-office mail and book deliveries between units, cancelling patron holds and requests on music library items, deciding where to store music library items returned to other units during our closure, and other such issues. Once we decided on a date to close the old library, we communicated that as widely as possible (Facebook, website, signage, $U$ of $M$ Libraries intranet). We communicated frequently with the DFoM, who were planning their own move to the same building. This was an excellent opportunity for collaboration with office staff in the DFoM, as we worked together to choose a moving company, juggle moving dates, share the elevators, and generally coordinate all movements.

\section{Moving Day (August 12-14, 2015)}

As stated above, I was the primary contact with the moving company; this was true not only in the weeks leading up to moving day, but remained true on the day itself, through texting and phoning the movers. I was on-site, telling movers where to park the truck, and working with them to determine the most efficient path into the new space. Each day, the moving crew changed, but their leader stayed the same and could train the new crew on procedures learned the day before.

Because library staff had devised a workflow and cart-labeling system in advance (see above), the physical move of the collection went very smoothly. The movers quickly understood the organization of the shelves, and the need to keep books and scores in order. Library staff worked efficiently to label each cart with the appropriate call numbers. The empty shelves in the new library had been pre-labeled, and library staff stationed in the new space showed the movers where to unpack each cart according to the labels. The books, scores, and LPs were moved with minimal disorder.

The CD, VHS, and DVD packing in the Frogboxes ${ }^{\mathrm{TM}}$ also went smoothly. The library staff had prepared these materials by grouping them into "bricks" of about 10-15 items per brick, using elastics to keep the bricks together. The bricks were stacked into the Frogboxes ${ }^{\mathrm{TM}}$ and each box was also numbered. In this way, we kept the boxes in approximate call number order. The movers, when unpacking the bricks, only had to sort them numerically on the shelves (see fig. 11). There was no need for them to understand Library of Congress Classification. 


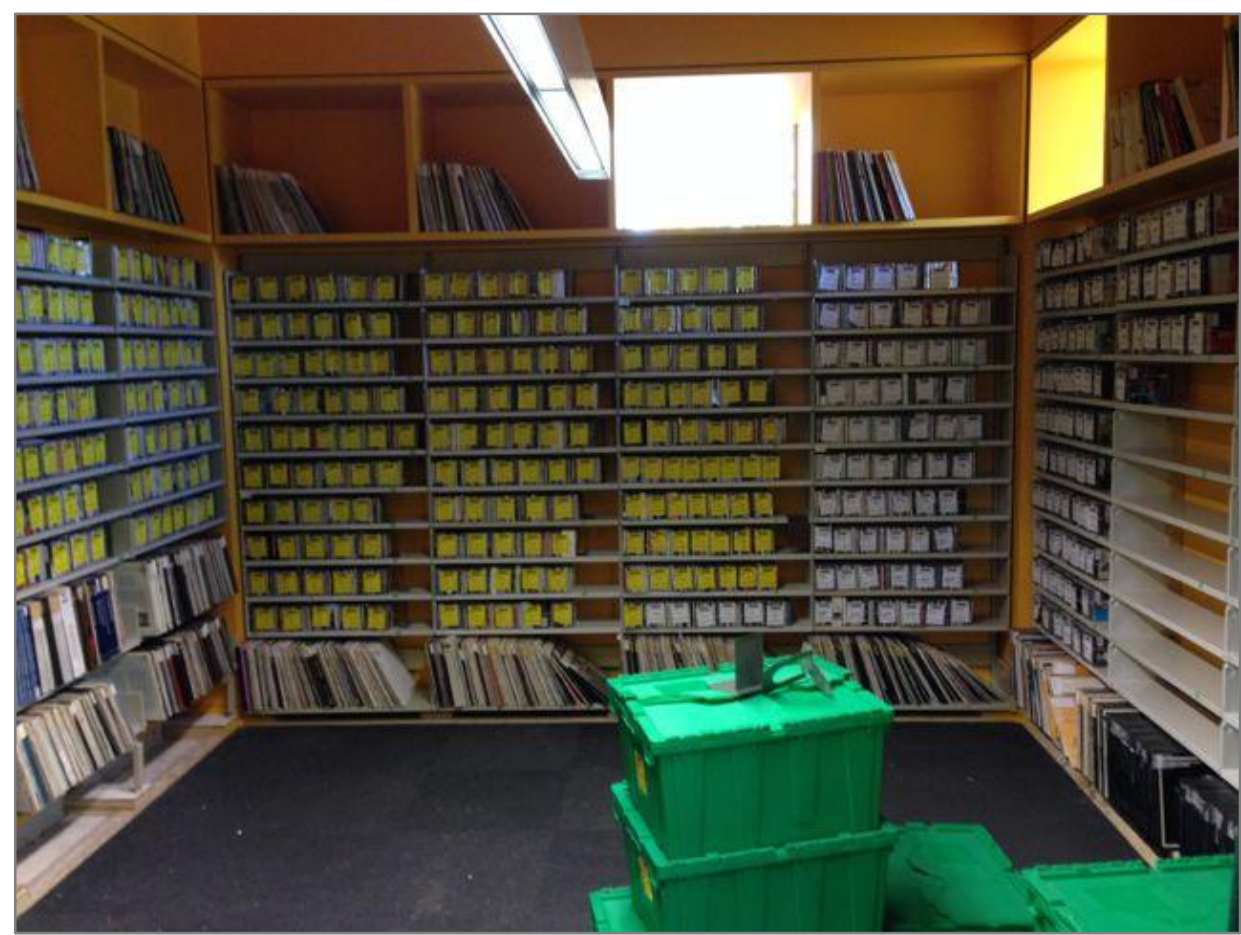

Figure 11. Numbered "bricks" of CDs, with Frogboxes ${ }^{\mathrm{TM}}$

\section{Post-Move (August 2015- present)}

There are many, many loose ends and tasks to complete after a library move. Our construction contract came with a two-year warranty; if any of the work in the contract is found to be incomplete or faulty within two years, the construction company is obligated to remedy the situation.

In the days, weeks, and months following moving day, library staff found themselves working in a construction site. Having moved the library in mid-August, our plan was to re-open to the public in time for the beginning of the Fall semester, just after Labour Day. However, although major work in the Library was completed, there were many loose ends that delayed our re-opening:

- Installation of 3M security gate

- Installation of keypad alarm system

- Completion of millwork in listening room, to be followed by installation of library shelving in listening room and unpacking CDs, miniature scores, VHS and DVDs

- Installation of wi-fi

- Delivery and assembly of staff desks

- Removal of old/temporary staff desks

- Delivery and assembly of student tables, listening room carrels, and audio equipment cabinets

- Removal of old/temporary student tables

- Pulling electricity from the floor to power student tables, carrels, and audio cabinets

- Installation of public computers (once student tables were on-site) and public printing station

- Installation of LCD monitors in group study room (1), and at library entrance (2) 
Meanwhile, construction work was ongoing in the classrooms and corridors outside the Library. Staff were often disrupted by intermittent but intense jackhammering or drilling, sometimes to the point of needing to relocate to other workspaces on campus. Surplus shelving and furniture in the aisles of the book stacks had to be removed for safety reasons prior to re-opening. The library staff had to track all the loose ends, and follow up with the project manager, the library facilities manager, and the campus IT department. In many cases we did not know whom to contact, and it took time to figure this out. For example, we had to change our campus address in all University publications and on the website, and arrange for our mail to be delivered to the new location. Such seemingly trivial matters could sometimes take several hours of staff time to sort out.

Another consideration for a new library space is identifying and allocating funds for new office supplies. Realizing we would need new range finders on the end panels of our shelves, we consulted with the User Experience Librarian and the sign shop in Physical Plant on appropriate size and positioning. We also knew we would no longer be satisfied using old coffee tins to hold paper clips and elastics on our desks or as cupboard organizers. Once we moved to the new space and staff lived in it for a while, we began a list of office supplies to make our space more functional and attractive.

Communication continued to be crucial during the post-move period. We updated our Facebook page, website, and the $\mathrm{U}$ of $\mathrm{M}$ Libraries intranet weekly between moving day and opening day. We made many paper signs to post on the door of the Library to indicate when we might re-open. We re-opened in mid-September with closed stacks, then opened fully in late September. Once we were fully open, we frequently communicated with patrons (signage, Facebook, website) to indicate which services were available (e.g., power outlets for laptops) and which were coming soon (e.g., wi-fi). There was no wayfinding signage within the Taché Arts Complex for the first several months after the Library re-opened to the public, and visitors reported difficulty finding their way to the library from the building's street entrances. We consulted with the DFoM and got permission to post temporary way-finding signs at all building entrances.

\section{Lessons Learned}

\section{Don't assume anything!}

We made many assumptions over the course of eight years, many of which proved false. For example, I had reviewed the mechanical drawings in 2013 with the Project Coordinator (see above) and determined the number and placement of power and data outlets. I assumed the campus IT department would also be invited to review the drawings, to give input on placement of outlets and data ports in relation to the actual computers, printers, copiers, and card readers. In fact, there was no such consultation built into the process, but I did not find that out until the renovation was complete and the IT workers arrived to install the computers. It is up to the librarian to ensure the IT department is brought in early and often to the planning and design process. 
In another case, we assumed the Interior Designer would check measurements for the audio equipment cabinets we had specified against the height and depth of the tables she selected, to ensure the cabinets would fit underneath. When the custom-built audio cabinets arrived, they did not fit under the tables, resulting in many modifications. This delayed the availability of the listening equipment to the students by about three months after the library re-opened.

Don't assume the University Librarian is keeping tabs on your library building project or is setting money aside for new furniture or office supplies. University Librarians only know what you tell them, so ensure you provide regular updates. If you need library administration to fund furniture and office supplies, you must provide a detailed budget years ahead, and update it every year to keep it on the radar.

Don't assume that Vancouver-based architects will think to allocate space in the staff lounge for puffy parkas and winter boots. In Winnipeg, winter outerwear is a serious space consideration for several months of the year; in Vancouver it is not. It is therefore worth mentioning such specific needs of staff and patrons.

Library staff must make many, many decisions during a construction project, and it can be comforting to make assumptions since one cannot possibly control every detail of the design and implementation. However, incorrect assumptions can lead to a false sense of security. The safer bet is to write down all questions and assumptions along the way, and check in regularly with the project manager. As the project gets close to completion, check-ins should become more frequent: from monthly, to weekly, to daily, to several times per day.

\section{Ask Questions and Document Everything}

Any construction project involves many people with whom librarians may not have much experience: architects, budget officers, tradespeople, moving companies, and construction managers, to name a few. Everyone is busy, and they often have multiple projects on the go, not just yours. Each of these groups has its own jargon, acronyms, and terminology, and it can be intimidating for the librarian who needs to learn how to speak to each group and to inform each group about library issues.

The librarian should keep a running list of all questions and concerns regarding the construction project, and not be afraid to speak out. If the librarian is the main point of contact, there will be opportunities to make inquiries at construction meetings. The librarian should also have a stack of business cards handy: the tradespeople and contractors I met at such meetings handed out business cards to everyone present, and expected them from me in return. If the librarian's supervisor is the main point of contact, it is important to put each question and concern in writing. Each person involved wants the project to succeed.

Many important conversations about the project take place over the phone or face-to-face. The librarian must follow up each such conversation with an e-mail to provide documentation for all parties. There 
are too many variables and decisions to rely on human memory. I recommend archiving each e-mail for future reference.

\section{People \& Communication}

Because so many people are involved in a construction project, the librarian will need to set aside time each day for communication. This includes e-mailing appropriate people with questions and concerns (sometimes several times per day) and being able to drop everything to spend half an hour talking to a carpenter/painter/plasterer who has questions about what they're building/painting/plastering. You will need time to find the right person to ask, and then more time to write a follow-up e-mail. Often the tradespeople will arrive to complete a task when the librarian is not present; it is rare that they will call ahead. In that case, the librarian may spend the rest of the morning tracking down the tradesperson to answer questions, or to find out what work was completed, and then to follow up with an e-mail.

In addition to all the above communication, the librarian must keep all staff in the library informed of the progress of the construction. This should happen both through regular e-mails and regular face-toface meetings. The staff need a venue to voice their many questions. Once physical construction starts, staff may interact with the tradespeople when the librarian is out of the office. The librarian should copy all staff on e-mails so they know to expect certain work on certain days, which tradespeople they might expect to see when, and which questions they should ask. This may result in overloaded inboxes, but a dearth of information can lead to staff confusion, misunderstanding, and delays or mistakes.

Smartphones are essential for all staff involved before, during, and after the move. On moving day, we used smartphones with each other and with various tradespeople and movers. We texted, looked up phone numbers and e-mail addresses on the fly, and also took photos of the project as it progressed. In addition, photos of moving boxes at the old library were sent to the new library, so staff knew what to look for.

\section{Delegate/Involve All Staff}

Library staff will have many questions about the construction project as it progresses, and they will also have important insights for decision-making. For example, if the architect requires information about storage needs at the service counter and around staff work areas, bring the staff into that conversation, since they use those spaces most often and will have valuable input. Decision-making takes more time when more staff are involved, so the librarian should plan accordingly.

In some circumstances, delegating responsibilities to some or all library staff can save the librarian time. The librarian needs to make myriad decisions, and delegation can also provide a measure of relief from decision fatigue. At the Eckhardt-Gramatté Music Library, library staff were given responsibility for many tasks, including (but not limited to): 
- Signage before, during, and after the move

- Inventory and mapping of office supplies from cupboards and shelves in the old library to cupboards and shelves in the new location

- Liaison with the Audio/Visual Classroom Technology department to coordinate disassembly, moving, and re-assembly of audio equipment

- Creating a spreadsheet to help with shelving space planning (see discussion of Fortreide book above)

- Coordinating volunteers from other libraries to help clean and label shelves and shelf-read after the move

\section{Be Patient and Ask for Help}

With any building project, the librarian must accept delays and mistakes along the way. Architects, designers, tradespeople, and library staff will ask hundreds of questions each week, and finding answers and making decisions is time-consuming and exhausting. Keep in mind that you don't have to answer everyone's questions immediately; take time to prioritize tasks and respond to questions in a logical sequence. Give yourself time away from e-mail each day, even if it's only 30 minutes. Delegation of decision-making and fact-finding (as described above) can help the librarian manage this workloaddon't be afraid to ask for help! If the library has a facilities manager, ensure he/she is involved in the planning and design from the beginning of the project. Facilities managers can be useful conduits of information to Physical Plant. They understand how work orders should be completed, and will track things like security systems, thus relieving the librarian of some responsibilities.

Because this building project took many years, unforeseen staff turnover inevitably caused delays. The Coordinator position in Physical Plant changed hands three times; a different construction company came on board mid-way; a new Interior Designer joined the team in early 2015. Each time such a change happens, it takes time for the new person to get up to speed.

\section{Final Thoughts}

I consider myself very fortunate to have been involved in the planning, design, and move of the Eckhardt-Gramatté Music Library from the beginning to the end. In addition to a beautiful new library space, I gained valuable experience in project management and leadership, a deep understanding of the budgeting and decision-making structures at a large research institution, a stronger relationship with the Desautels Faculty of Music, and a profound respect for the skilled trades. I honed my communication skills, and was continually humbled by the patience, good humour and teamwork shown by my incredible support staff. Any library building project will take an immense toll on your time, your knowledge and skills, and your energy. For me, the benefits of this project have greatly outweighed these costs. 


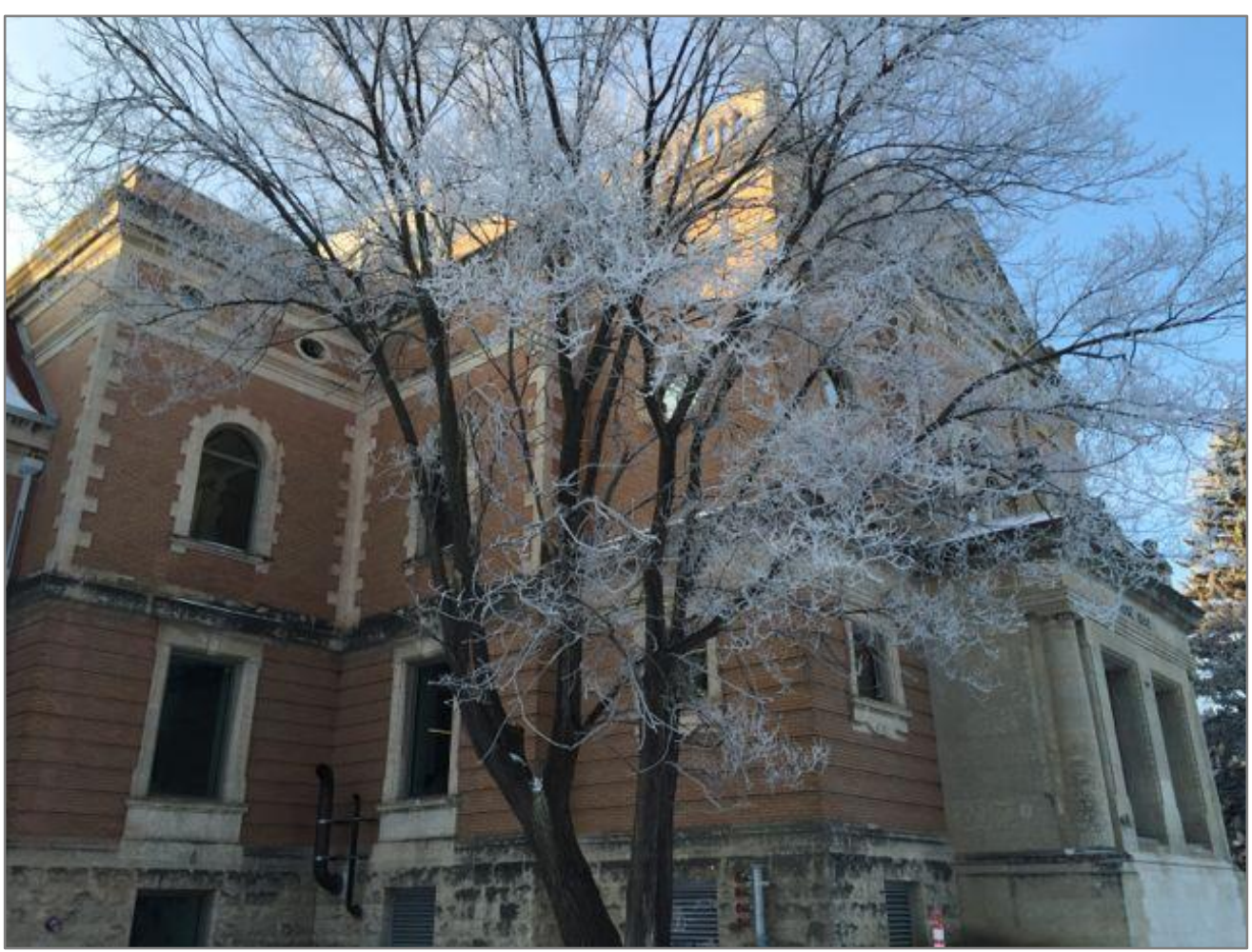

Figure 12. Taché Arts Complex (exterior of Music Library)

\section{References and Recommended Readings}

American Institute of Architects. 2016. Architectural Graphic Standards. 12th ed. Edited by Dennis Hall. Hoboken, NJ: John Wiley \& Sons.

Association of College and Research Libraries. 1990. Guidelines for Media Resources in Academic Libraries. http://www.ala.org/acrl/standards/mediaresources.

. 2011. Standards for Libraries in Higher Education. http://www.ala.org/acrl/standards/standardslibraries.

Award of Excellence: Centre for Music, Art and Design. 2005. Canadian Architect 50 (12): 32-33.

Binggeli, Corky. 2012. Interior Graphic Standards. 2nd ed. Wiley Graphic Standards. Hoboken, NJ: Wiley.

Cassaro, James P. 1991. Space Utilization in Music Libraries. MLA Technical Report No. 20. Canton, MA: Music Library Association. 
Farrington, Jim. 2006. Audio and Video Equipment Basics for Libraries. Canton, MA: Music Library Association.

Fortriede, Steven. 2010. Moving Your Library: Getting the Collection from Here to There. Chicago: ALA Editions.

Freeman, Geoffrey T. 2005. "The Library as Place: Changes in Learning Patterns, Collections, Technology, and Use." In Library as Place: Rethinking Roles, Rethinking Space, CLIR, 1-9. Washington, DC: Council on Library and Information Resources. https://www.clir.org/pubs/reports/pub129/pub129.pdf.

Functional Program: University of Manitoba Centre for Music, Art and Design. 2003. LM Architectural Group / Patkau Architects Inc.

Guise, Janneka L. 2010. “Eckhardt-Gramatté Music Library Space Plan.” Unpublished report. Winnipeg, MB: University of Manitoba.

Music Library Association. 2010. Music Library Facilities Bibliography. http://facilities.musiclibraryassoc.org.

Music Library Association and National Association of Schools of Music. 1994. Local Assessment of Music Libraries and Information Services: The Present and the Future. Canton, MA: Music Library Association. 